\section{特集 肝 胆 膵 疾 患 診断と治療の最先端}

順天堂医学 $45(4)$ p. $486 \sim 496(2000)$
胆囊結石・胆嚢隆起性病変の治療の

\section{適応についての検討**}

\title{
Study of the therapeutic indication of cholecystolithiasis and elevated lesion of the gallbladder
}

\author{
窪 川 良 廣* \\ YoshIHIRo KUBOKAWA
}

崔仁 煥*

JINKAN SAI

\author{
有山襄* \\ JoE ARIYAMA
}

山 中 晃一郎*

KOICHIRO YAMANAKA

\author{
須 山 正 文* \\ MASAFUMI SUYAMA \\ 中 野一 永* \\ KAZUNAGA NAKANO
}

胆石合併急性胆䨣炎 50 例・各種胆霅隆起性病変 204 例について検討した。急性胆囊炎で緊急 手術を行った例は, 症状が強く炎症反応が高い例・抗生剤の無効な例・腹膜刺激徴候を有する 例・肝膿瘍合併例・胆霊穿孔例であった，27例には症状の消失後，待機的手術を行った．基礎 疾患を有する例，手術を拒否した例 13 例は手術を施行せず，抗生剤を投与し，抗生剤の無効で あった 3 例にPTGBD を行い，症状は消失した．急性胆輁炎において，血液生化学検査所見では 炎症反応が重症度と相関し，USでは全例に急性胆囊炎の所見がみられ，急性胆震炎の診断に有 用であった，急性胆震炎は基礎疾患がなければ手術の適応となるが，保存的治療から緊急手術， PTGBD へ踏み切る時期は, 抗生剤の無効な例では 2 日から遅くても 3 日以内と考えられた。胆

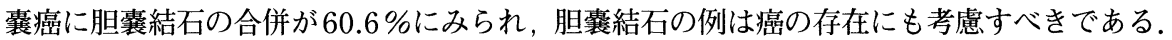

胆囊隆起性病変切除例の内訳はコレステロールポリープ87例・腺筋腫症 (localized type ) 24 例・炎症性ポリープ4例・過形成ポリープ 6 例・腺腫 12 例・早期癌 21 例・進行癌 50 例である. コレステロールポリープは $88.5 \%$ が $10 \mathrm{~mm}$ 以下で，大きな病変ほど癌の比率が高くなった。コ レステロールポリープのEUSによる正診率は $78.6 \%$ あっった．腺筋腫症のEUSによる診断率は $57.9 \% て ゙$ localized type の例は癌との鑑別が困難な例が多く, 腺腫では均一な高エコーの例が特 徵的であった。胆囊癌で存在診断ができた例では全例術前に癌と診断した。コレステロールポリ 一プと診断できない例, $10 \mathrm{~mm}$ 以上の病変では癌の可能性を考慮し, 精査・手術を検討する必要 がある。

キーワード : 胆襄結石, 急性胆襄炎, 胆震ポリープ, 胆囊癌, 超音波

Key words : cholecystolithiasis, acute chdecystitis, gallbladder polyp, gallbladder carcinoma, ultrasonography

*順天堂大学医学部内科学教室消化器内科学講座

Division of Gastroenterology, Department of Internal Medicine, Juntendo University School of Medicine, Tokyo, Japan

**第290 回順天堂医学会学術集会〔Sept. 16, 1999 開催〕

[Nov. 25, 1999 原稿受領] 


\section{はじめに}

画像機器の進歩により, 胆囊結石および胆䡛ポ リープをはじめとする胆囊隆起性病変は体外式超 音波検査で容易に拾い上げられ，各種精査により 高率に質的診断が可能となった。通常，胆囊結石 に急性胆囊炎を併発した場合は治療を必要とする が, 手術等を行う時期について一定の見解はない. 胆震の隆起性病変は癌と診断されれば切除を検討 する必要があるが， $2 \mathrm{~cm}$ 以下の小隆起では良悪性 の鑑別が困難な例もあり手術適応が問題となる. 今回, 胆囊結石・胆囊隆起性病変について自験例 を中心に治療の適応について検討した。

\section{対象と方法}

対象は急性胆囊のために入院治療をした胆囊結 石 50 例と病理組織学的に診断された胆囊癌 71 例 を含む各種胆囊隆起性病変の切除例204例である （表-1）。急性胆襄炎例は男性 31 例·女性 19例, 年歯交 20 歳から 88 歳, 平均 60.4 歳であった. 胆 囊隆起性病変は良性例では男性 80 例・女性 53 例 で, 年歯岺は 26 歳から 85 歳, 平均 54.3 歳, 悪性例 は男性 30 例・女性 41 例で年齢は 33 歳から 85 歳, 平均 64.5 歳であった。

急性胆囊炎は，行われた治療の種類別に臨床症 状・血液検査所見・体外式超音波（以下US）所 見, 症状の再発の有無を調へ，胆石の治療の適応 について検討した，急性胆震炎の治療は手術治療 を原則とした。

胆霊隆起性病変は病理組織診断別に病変の大き

表-1 対 象

男女比 年 齢 (平均)

\begin{tabular}{|c|c|c|c|}
\hline 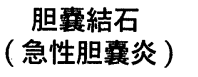 & 50 例 & $31: 19$ & $20 \sim 88$ 歳 $(60.4)$ \\
\hline $\begin{array}{c}\text { 胆曘隆起性病変 } \\
\text { 良 性 } \\
\text { 癌 }\end{array}$ & $\begin{array}{r}204 \text { 例 } \\
133 \text { 例 } \\
71 \text { 例 }\end{array}$ & $\begin{array}{l}80: 53 \\
30: 41\end{array}$ & $\begin{array}{l}26 \sim 85 \text { 歲 }(54.3) \\
33 \sim 85 \text { 歲 }(64.5)\end{array}$ \\
\hline
\end{tabular}

さ, US，超音波内視鏡 ( 以下EUS ) 所見につい て検討し，切除の適応を検討した。

\section{胆囊結石}

\section{1. 急性胆襄炎の治療}

胆石で急性胆輁炎を発症した50例について行 われた治療を表- 2 に示した。胆囊摘出術は 37 例 に施行され，10例は緊急手術を，27例は抗生剤 等により症状が消失した後,待機的手術を行った。 緊急手術は全例開腹手術で，待機的手術の例では 10 例が開腹手術で，17例は腹腔鏡下胆輁摘出術 を行った．非手術例は 13 例で 10 例は抗生剤を中 心とした保存的治療で，3例は経皮経肝胆囊ドレ ナージ (PTGBD ) を施行した。

2. 各種治療例の概要

緊急手術が行われた例は症状が強く，炎症反応 が高值であった 3 例，抗生㓮を使用したが疼痛が 改善しなかった 2 例，5日間 $38^{\circ} \mathrm{C}$ 台の発熱が続い た例，入院 2 日後に $38^{\circ} \mathrm{C}$ 台まで発熱した例，およ び受診時に腹膜刺激徵候がみられた例，朋膿瘍を 合併した例，胆震穿孔例が各 1 例の計 10 例であっ た。当初抗生剤投与で観察された 4 例のうち 5 日 間解熱しなかった 1 例を除いて 2 日以内に緊急手 術が行われた。 27 例は抗生剂で臨床症状が軽快 した後, 胆襄摘出術を行った.

手術を行わなかった10例のうち6例は他の基礎 疾患を有しており，内訳は肝硬変 3 例・脳梗塞 1 例・呼吸機能障害 1 例・ 心機能障害 1 例で, 他の 4例は手術を勧めたが拒否した例であった。

表-2 急性胆震炎の治療

\begin{tabular}{|c|c|c|}
\hline \multirow[b]{2}{*}{ 手 } & 緊急手術 & 10 例 \\
\hline & 開腹手術 & 10 例 \\
\hline \multirow{3}{*}{ 術 } & 待機的手術 & 27 例 \\
\hline & 開腹手術 & 10 例 \\
\hline & 腹腔鏡下 & 17 例 \\
\hline 非 & PTGBD & 3 例 \\
\hline 術 & 保存的治療 & 10 例 \\
\hline & 計 & 50 例 \\
\hline
\end{tabular}


PTGBD を行った 3 例は全例他の基礎疾患を合 併しており, 肝硬変が 1 例, 心機能障害が 1 例, 腎不全が 1 例で，抗生剤を 2 日まで使用しても臨 床症状に改善がみられなかった例であった。

3 . 急性胆輁炎の症状

受診時の自覚症状は, 50 例のうち胸部痛, 嘔 吐の各 1 例を除いて上腹部痛を主訴とし, 胆囊に 一致した右季肋部痛は26例 $(52 \%)$ であった. 4 例は背部痛もみられた。腹膜刺激徵候は 9 例に認 められ，緊急手術例に 2 例, PTGBD 例に 1 例で, 6例は抗生剤で症状は消失した。

\section{4. 胆石の保有年数と発作の回数}

治療の種類に関わらず過去 1 年以内に指摘され た例が 32 例 $(64 \%)$ と多かったが，5年以上前 に指摘された例も 9 例 (18\%) 存在した.

入院治療までに生じた発作の回数は, 26 例 $(52$ \%) が初回の発作で入院しており，2回目までに 36 例 $(72 \%)$ が入院治療をした。9例（18\%） は4回以上の発作を経験していたが, 発作の回数 と手術の緊急性の有無とは関連がみられなかっ た。

\section{5. 血液検査所見}

急性胆囊炎の入院時の炎症反応を表-3に示し た。緊急手術例・PTGBD 施行例を緊急例とする
と, 緊急例では 2 例を除いて白血球が $10,000 / 1$ 以上に上昇していたが, 待機的手術, 保存的治療 の非緊急例では $10,000 / 1$ 以上に上昇していた例 はそれぞれ $33.3 \% ， 30.0 \%$ とどまった.CRP では緊急例は全例 $10 \mathrm{mg} / d 1$ 以上と高值を示した のに対し, 非緊急例 37 例では30例 $(81.1 \%)$ で 異常值を示したものの, $10 \mathrm{mg} / \mathrm{d} 1$ 以上に上昇し た例は11例 $(29.7 \%)$ にとどまった.

腹膜刺激徴候を示した 9 例のうち緊急例 3 例は 白血球が $10,000 / 1$ 以上で, かつCRPも $10 \mathrm{mg} /$ dI以上であったが, 非緊急例では白血球と CRP がともに高值であった例は存在せず，炎症反応は 治療の指標となり得た。

表-4，-5に急性胆囊炎の受診時の胆道系酵素， transaminaseについて示したが，胆道系酵素の いずれかが異常值を示した例は $60 \%$ にとどまり， 緊急性とも関連が認められず，transaminaseに ついても同様であった。

6. 急性胆震炎のUS像

急性胆輁炎50例の受診時のUS所見を表-6に示 した. 全例に胆囊炎を示唆する所見が描出できた. 胆囊壁の肥厚は 48 例 $(96 \%)$ にみられ，さらに 急性胆霟炎に特徴的とされる三層構造は 32 例 ( 64 \% ）に認められた。胆輁の腫大は軽度な例, 著明

表-3 急性胆震炎と炎症反応

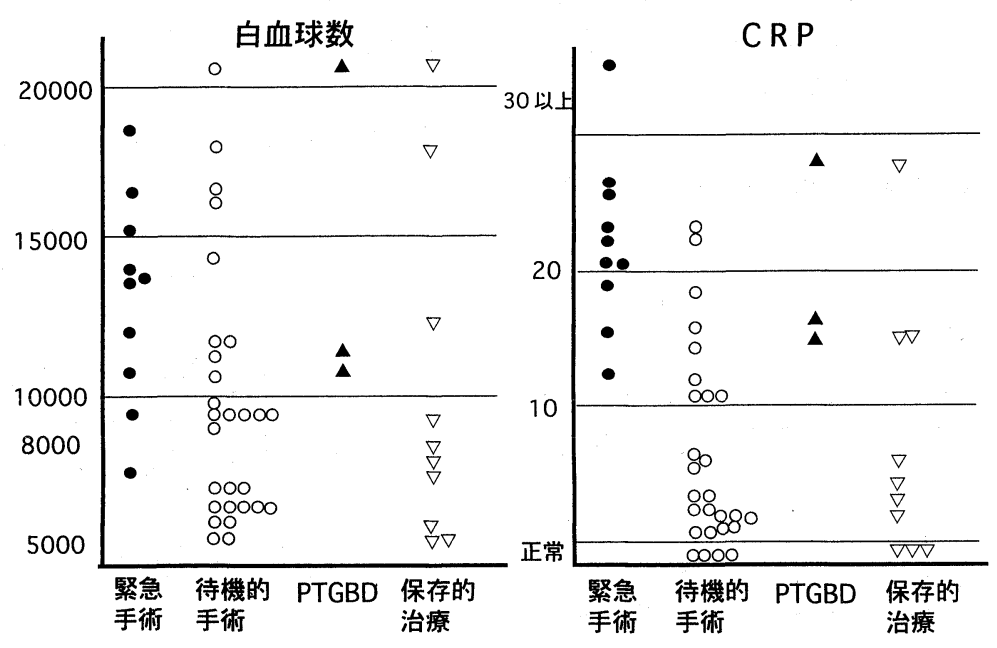


表-4 急性胆軎炎と胆道系酵素
A L P
LDH $r$ G T P

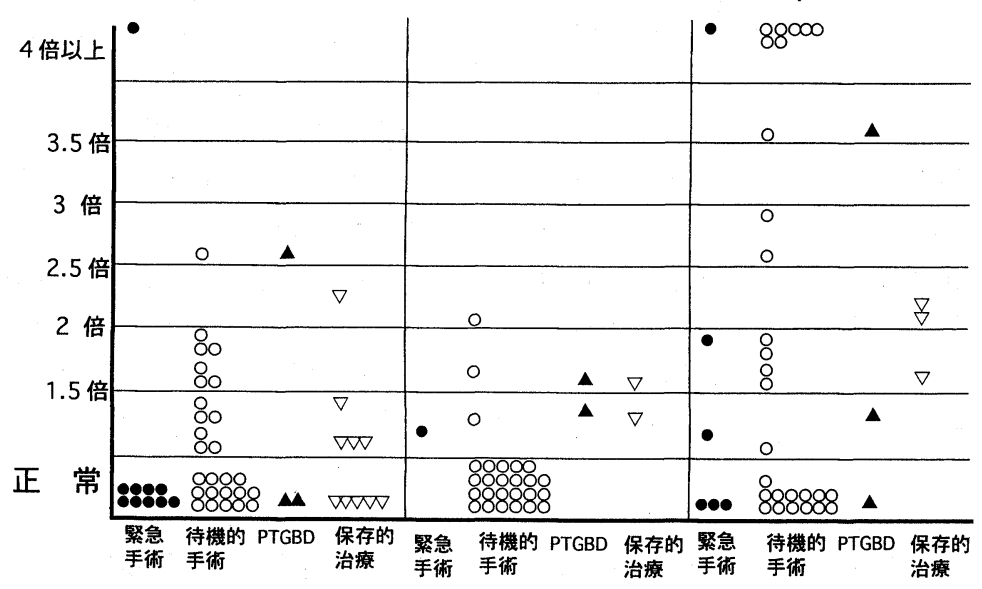

表-5 急性胆囊炎と transaminase

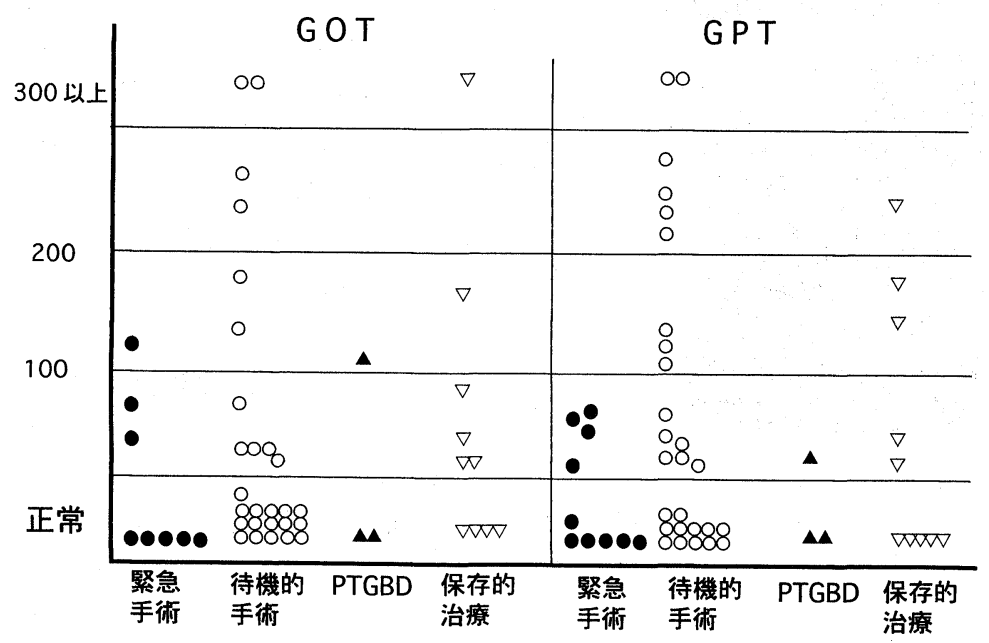

表-6 急性胆震炎のUS像

\begin{tabular}{|c|c|c|c|c|c|}
\hline & $\begin{array}{c}\text { 緊急手術 } \\
10 \text { 例 }\end{array}$ & $\begin{array}{c}\text { 待機的手 } \\
27 \text { 例 }\end{array}$ & $\begin{array}{l}\text { PTGBD } \\
3 \text { 例 }\end{array}$ & $\begin{array}{c}\text { 保存治療 } \\
3 \text { 例 }\end{array}$ & $\begin{array}{l}\text { 計 } \\
50 \text { 例 }\end{array}$ \\
\hline $\begin{array}{l}\text { 壁 肥 厚 } \\
\text { (三層構造) }\end{array}$ & 10 & 27 & 3 & 8 & $\begin{array}{c}48 \\
(32)\end{array}$ \\
\hline 胆䘫脿腫大 & (10) & (15) & (3) & & \\
\hline $\begin{array}{ll}\text { 著 } & \text { 明 } \\
\text { 軽 } & \text { 度 }\end{array}$ & $\begin{array}{r}10 \\
0\end{array}$ & $\begin{array}{r}13 \\
5\end{array}$ & $\begin{array}{l}3 \\
0\end{array}$ & $\begin{array}{l}6 \\
2\end{array}$ & $\begin{array}{r}32 \\
7\end{array}$ \\
\hline 浸出液 & 2 & 4 & 0 & $\overline{0}$ & 6 \\
\hline 肝 膿 瘍 & 1 & 1 & 1 & 0 & 3 \\
\hline
\end{tabular}


な例を合わせて 32 例 $(64 \%)$ にみられた. 胆囊 周囲の浸出液が 6 例に, 肝膿瘍が 3 例に描出され, 急性胆襄炎の診断にはUSが有用であった. 図-1 に緊急手術を行った胆囊穿孔例のUS像を示す.

7. 抗生剂の効果

待機的手術例 - 保存的治療例の 37 例について 抗生剤を投与してから自覚症状が消失するまでの 日数を検討した。抗生剤投与後 2 日までに 26 例 (70.3\%)，3日までに 34 例 ( $91.9 \%)$ に症状の消 失がみられ，5日目までに全例で症状が消失した。

8. 非手術例の退院後の経過

手術せず胆囊結石を有したまま退院した 13 例 の退院後の経過を調査した，保存的治療のみ行わ れた 10 例のうち 2 例に 8 力月後, 1 年後に症状の

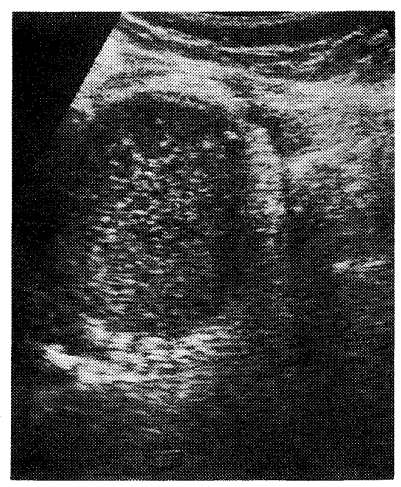

図-1 急性胆豪炎,胆襄穿孔例のUS像

胆震は壁肥厚, 腫大が著明で, 内部に結石, sludgeの充満 が認められ，さらに胆囊周囲の浸出液もみられた
再発がみられたが, 無治療で症状は軽快した。 PTGBD を行った 3 例のうち 1 例は退院後 2 力月で 急性胆囊炎が再発し, 多臓器不全で死亡した。

9. 胆囊癌と胆囊結石

当院で切除し病理学的に診断された胆囊癌 71 例のうち 43 例 $(60.6 \%)$ に胆需結石の合併が認 められた．胆囊癌の無症状例のうち胆囊結石の経 過観察例7例から胆囊癌が発見され，全例進行癌 であった. 表-7に切除 71 例のUS所見を示した。 71 例中 15 例 $(21.1 \%)$ が術前に結石・急性胆震 炎のために癌の存在診断ができなかった。

USで胆囊結石を観察する際，癌の併存に注意 して観察する必要がある.

10．胆襄結石の治療の適応

上腹部痛を有する胆囊結石例は手術を検討す る. 症状が強く, 炎症反応の高い例, 肝膿瘍を合 併する例, 抗生剤を投与して 2 日から 3 日以内に 症状が改善しない例は緊急手術を考慮する．基礎 疾患を有し，手術に危険を伴う例は抗生剂等の保 存治療を行うが, 緊急手術の適応となるような症 例にはPTGBD を検討する，充満結石例・急性胆 囊炎例では癌の併存が診断できないことがあり， USによる観察は注意が必要である.

\section{胆囊隆起性病変}

\section{1. 胆震隆起性病変と大きさ}

切除し, 病理組織学的に診断された各種胆囊隆

表-7 切除胆震癌のUS 所見 $(\mathrm{n}=71)$

（）は\%

\begin{tabular}{|c|c|c|c|c|c|c|c|c|c|c|}
\hline & $\begin{array}{l}\text { 全周性 } \\
\text { 壁肥厚 }\end{array}$ & $\begin{array}{l}\text { 限局性 } \\
\text { 壁肥厚 }\end{array}$ & 腫 演 & $\begin{array}{l}\text { 乳頭状 } \\
\text { 隆 起 }\end{array}$ & $\begin{array}{l}\text { 結節状 } \\
\text { 隆 起 }\end{array}$ & $\begin{array}{l}\text { 有茎 } \\
\text { polyp }\end{array}$ & debris & $\begin{array}{l}\text { 結石 } \\
\text { のみ }\end{array}$ & $\begin{array}{l}\text { 急 性 } \\
\text { 胆㤟炎 }\end{array}$ & その他 \\
\hline \multirow{2}{*}{$\begin{array}{l}\text { 早期癌 } \\
(n=21)\end{array}$} & 2 & 1 & 2 & 1 & 1 & 7 & 1 & 3 & 3 & 0 \\
\hline & (9.5) & (4.8) & (9.5) & (4.8) & (4.8) & (33.3) & (4.8) & (14.3) & (14.3) & \\
\hline \multirow{2}{*}{$\begin{array}{l}\text { 進行癌 } \\
(n=50)\end{array}$} & 7 & 6 & 22 & 2 & 1 & 0 & 1 & 4 & 5 & 2 \\
\hline & $(14.0)$ & $(12.0)$ & $(44.0)$ & $(4.0)$ & $(2.0)$ & & $(2.0)$ & $(8.0)$ & $(10.0)$ & $(4.0)$ \\
\hline
\end{tabular}


起性病変 204 例について病変の大きさを示した (表-8). 隆起性病変の内訳はコレステロールポ リープ 87 例・腺筋腫症 (localized type ) 24 例 · 炎症性ポリープ4例・過形成ポリープ6例・腺腫 12 例・早期癌 21 例・進行癌 50 例である.コレス テロールポリープは77例 $(88.5 \%)$ が $10 \mathrm{~mm}$ 以 下で，最大が $20 \mathrm{~mm}$ であった. $11 \mathrm{~mm}$ から $20 \mathrm{~mm}$ になるとコレステロールポリープは少なく, 癌が 混在し， $21 \mathrm{~mm}$ 以上の大きさになると腺筋腫症 5 例を除いてすべて癌であった。

胆囊の隆起性病変では $10 \mathrm{~mm}$ 以下はコレステ ロールポリープの比率が高く, 大きな病変ほど癌 の可能性が高くなった.

\section{2.コレステロールポリープの診断}

表-9にUS・EUSによるコレステロールポリー プの診断率を示した. US・EUSでは点状高エコ 一の多粒子構造の形態の有無から診断した（図$2,-3)$.USでは 86 例全例に存在診断ができ, 1 例はポリープが胆囊壁と接していたことから無茎 隆起として描出された. EUSは 42 例に行い, 33 例 $(78.6 \%)$ に正診できた.9例はコレステロー ルポリープの典型像が描出できず，1例を癌と診 断した. 正診できなかった例は病理組織学的に腺 増生の多い例, 内部で出血した例であった (図-4). 3. 腺筋腫症 (localized type) の診断率

腺筋腫症 (localized type) のUS・EUSの
診断率を表-10に示した. Rokitansky Aschoff sinus（RAS ) を反映する無エコー像, 壁内結石 を示す comet like echoの有無で評価した. US では正診された例は 24 例のうち 7 例 $(29.2 \%)$ のみで 14 例 $(58.3 \%)$ を癌と診断した. EUSを 行った 19 例では正診率は 11 例 $(57.9 \%)$ と上昇 したが，8例 $(42.1 \%)$ を癌と誤診した。

\section{4. その他のポリープの診断}

各種ポリープの病理組織学的な肉眼形態は, 腺 腫 11 例では 10 例が有茎で, 帚有茎が 1 例であっ た。炎症性ポリープ 4 例では, 有茎 1 例・亜有茥 2 例・無茎 1 例とさまざまな形態を示した。過形 成ポリープ6例は有茥 4 例・西有茥 2 例であった. 炎症性ポリープのうち 2 例は急性胆賷炎に併発 し, 過形成ポリープのうち 2 例は膵胆管合流異常 に発生した。

これらポリープのUS所見を表-11に示した。 腺腫 11 例中 10 例で存在診断ができ, 有茎性の病

表-9 コレステロールポリープの診断率

\begin{tabular}{c|lrl}
\hline U S S & 有蓕ポリープ & $86 / 87$ & $(98.9 \%)$ \\
& 無茎隆起 & $1 / 87$ & $(1.1 \%)$ \\
\hline \multirow{2}{*}{ E U S } & 正診 & $33 / 42$ & $(78.6 \%)$ \\
& ポリープ & $8 / 42$ & $(19.0 \%)$ \\
& 癌 & $1 / 42$ & $(2.4 \%)$ \\
\hline
\end{tabular}

表-8 胆輂隆起性病変と大きさ (切除例 $)(\mathrm{n}=204)$

\begin{tabular}{l|ccccc|c}
\hline 病変の大きさ $(\mathrm{mm})$ & $\sim 5$ & $\sim 10$ & $\sim 15$ & $\sim 20$ & $21 \sim$ & 計 \\
\hline コレステロ-ルポリ-プ & 36 & 41 & 8 & 2 & 0 & 87 \\
腺 筋 腫 症 & 1 & 8 & 6 & 4 & 5 & 24 \\
炎症性ポリ-プ & 1 & 2 & 0 & 1 & 0 & 4 \\
過形成ポリ-プ & 4 & 2 & 0 & 0 & 0 & 6 \\
$\quad$ 腺 腫 & 2 & 6 & 2 & 2 & 0 & 12 \\
早 期 癌 & 6 & 2 & 2 & 2 & 9 & 21 \\
$\quad$ 進 行 癌 & 0 & 0 & 1 & 3 & 46 & 50 \\
\hline
\end{tabular}




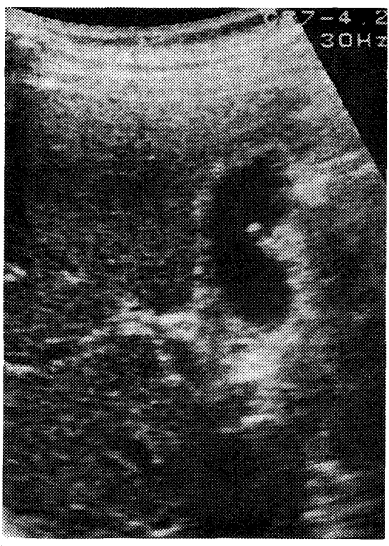

図-2 径 $3 m m$ のコレステロールポリープ, 切除例のUS像

点状高エコーとして描出された

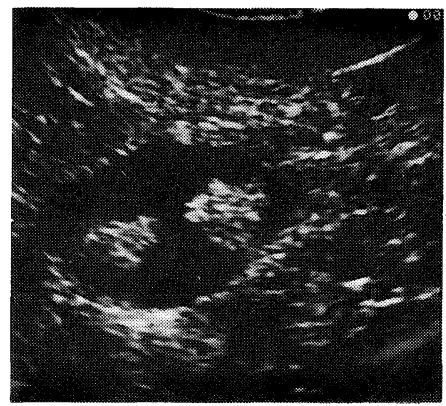

図-3 径 $10 \mathrm{~mm}$ のコレステロールポリープ, 切除例のEUS像

点状高エコーを有する形態が描出された

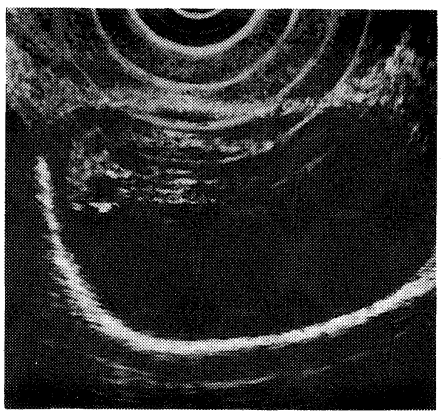

図-4 コレステロールポリープの切除例 EUSで内部に無エコーを有するポリープとして描出された. 病理組織標本で, 無エコーの部分は出血巣に一致した
表-10 腺筋腫症（localized type）の診断率

\begin{tabular}{|c|c|c|c|}
\hline$U S$ & 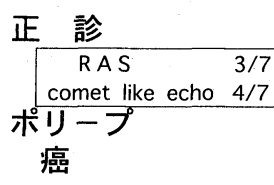 & $\begin{array}{r}3 / 24 \\
3 / 24 \\
14 / 24\end{array}$ & $\begin{array}{l}(29.2 \%) \\
(12.5 \%) \\
(58.3 \%)\end{array}$ \\
\hline EUS & 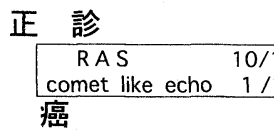 & $\frac{11 / 19}{11} \int_{8 / 19}^{11}$ & $\begin{array}{l}(57.9 \%) \\
(42.1 \%)\end{array}$ \\
\hline
\end{tabular}

表-11 各種隆起性病変のUS所見

\begin{tabular}{lccc} 
& $\begin{array}{c}\text { 腺 } \\
11 \text { 例 }\end{array}$ & $\begin{array}{c}\text { 炎症性ポリープ } \\
4 \text { 例 }\end{array}$ & $\begin{array}{c}\text { 過形成ポリープ } \\
6 \text { 例 }\end{array}$ \\
\hline 有茎ポリープ & 9 & 0 & 6 \\
亜有茎隆起 & 0 & 2 & 0 \\
無茎隆起 & 1 & 1 & 0 \\
描出不能 & 1 & 1 & 0 \\
\hline
\end{tabular}


変はすべて有茎ポリープと診断された。炎症性 ポリープでは急性胆囊炎1例で存在診断ができな かったが，他の 3 例は肉眼型に一致した所見が得 られた。過形成ポリープは全例に存在診断が可能 であった。

EUSを施行した例について所見を検討した ( 表-12). 腺腫 6 例は全例有茎性の病変で, 5例 $(83.3 \%)$ が均一な高エコーで, 1例は辺縁が高 エコー, 内部が低エコーであり，2例で太い茎が 描出された. 炎症性ポリープでは带有茎の 2 例に

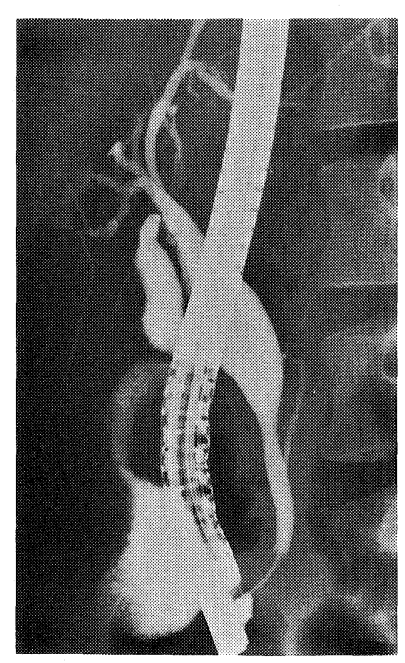

図-5 ERCPで膵胆管合流異常, 先天性胆管 拡張症と診断された
EUSが施行され，2例ともに亜有菱の形態が描 出され, エコーパターンは高エコー・低エコー各 1例であった。過形成ポリープでは有茎例 3 例に EUSが施行され，1例はコレステロールポリープ のエコーパターンであったが，1例は均一な高エ コー，1例は低エコーの有茎ポリープの所見で あった（図-5,-6).

\section{5 . 胆囊癌のUS所見}

胆囊癌のUS所見を表-7に示した。癌が存在診 断できた例ではそれぞれの肉眼型に一致したUS 像を呈した.他の隆起性病変と鑑別が必要な有荎 性の例（Ip型）の6例はすべて存在診断ができ， このうち4例にEUSを施行し均一な高エコーの所 見から癌, または腺腫と診断されたが, 癌と腺腫 の鑑別は困難であった (図-7)。径 $26 \mathrm{~mm}$ の乳頭

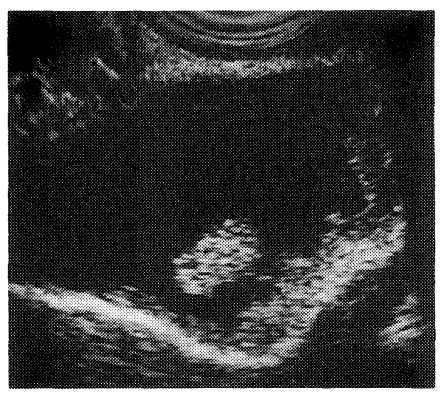

図-6 困-5と同症例のEUS像

胆震の内腔に乳頭状隆起が拡がり, 一部にやや高エコーのポ リープもみられた。癌の存在も疑って切除したが，過形成病変 であった

表-12 各種隆起性病変のEUS 所見

\begin{tabular}{|c|c|c|c|}
\hline & 6 例 & $\begin{array}{c}\text { 炎症性ポリープ } \\
2 \text { 例 }\end{array}$ & $\begin{array}{c}\text { 過形成ポリープ } \\
3 \text { 例 }\end{array}$ \\
\hline 有茎ポリープ & 6 & 0 & 3 \\
\hline 均一な高エコー & 5 & & 1 \\
\hline 辺緑高内部低エコー- & 1 & & 0 \\
\hline 等エコー & 0 & & 1 \\
\hline コレステロ-ルポリーフ & 0 & & 1 \\
\hline 亜有龿隆起 & 0 & 2 & 0 \\
\hline $\begin{array}{l}\text { 高エコー } \\
\text { 低エコー- }\end{array}$ & & $\begin{array}{l}1 \\
1\end{array}$ & \\
\hline
\end{tabular}




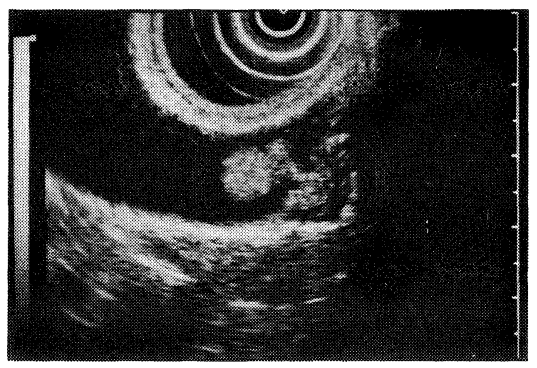

図-7 I p 型の腺腫内癌のEUS 像

太い茎を有し，均一なエコーパターンのポリープであった。 多くは腺腫で一部に腺癌が存在したが, 術前の癌と腺腫の区別 は困難であった

型の進行癌 1 例が US で有茎ポリープと診断され たが, EUSで癌と診断できた。

6 . 胆囊隆起性病変の取扱い

USでコレステロールポリープの典型像を示さ ないポリープ, $10 \mathrm{~mm}$ 以上の病変, RAS, 壁内結 石の所見を有さない無茎隆起は癌を疑いEUSを 行う必要がある. EUSでコレステロールポリー プ・腺筋腫症の所見がみられない病変は癌の可能 性を考慮し, 手術を検討する必要がある。

\section{考察}

腹部超音波検診による胆震結石・胆襄ポリープ の発見率は，それぞれ3〜4\%・3〜11\%1) 4) とされている。

1997 年度胆石全国調查報告 5 )では胆輁結石 2,454 例のうち $22.6 \%$ は無症状で, 腹痛・背部痛 を有する例が $72.1 \%$ あった。 無症状で発見さ れた胆襄結石の多くは症状のないまま経過する例 が多く, 有症状化してから対処するとの考えが多 い6）7）。急性胆囊炎の診断には超音波検査が有用 で, 胆囊の腫大, 胆囊䅡部に嵌頓した結石像, 胆 震壁の肥厚と sonolucent layer を有する三層構 造, 胆豪周囲の浸出液の貯留, 膿瘍の所見がみら れる8).

今回の急性胆䡛炎の検討でも, USでは全例に 急性胆輁炎を示唆する異常所見が描出され, 胆囊
周囲の浸出液, 肝膿瘍の描出にも有用であった. 治療としては開腹手術に比べて侵襲の少ない腹腔 鏡下胆囊摘出術が安全に行えるようになり ${ }^{9)}$, 胆 囊摘出術が一般的である. 手術の時期については, 緊急手術と待機的手術のどちらを選択するか意見 の一致をみていないが, 汎発性腹膜炎を併発して いるような場合は緊急手術の適応である ${ }^{8)}$.

自験例の緊急手術, PTGBDを行った理由とし て, いずれも腹部症状が強く, 腹膜刺激徴候を有 する例, 炎症反応の高值な例, 抗生剂が無効な例, 肝膿瘍合併例などである．重症度の判定には炎症 反応も有用であった．今回の検討では保存的治療 から緊急治療へ移行した 7 例中 6 例が 2 日以内に 緊急手術またはPTGBDが行われており，保存的 治療で症状が軽快した例も 2 日までに $70.3 \%, 3$ 日までに $91.9 \%$ 症状の消失がみられ，保存的 治療が無効な例での緊急治療へ踏み切る時期は, 2 日後, 遅くても 3 日後までが妥当と考えられた。 胆囊結石に胆囊癌が合併する頻度は1997年の

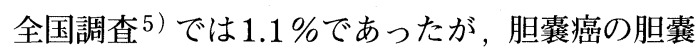
結石合併率は胆霊癌 38～54\%で 10) 11) と高率で ある。また初発症状の $12 \%$ 熏症胆輁炎との報 告がある12). われわれの検討では胆囊癌の $60.6 \%$ に胆囊結石の合併がみられ，切除胆囊癌の $21.1 \%$ が胆囊結石・急性胆囊炎のために術前に存在診断 ができず，また胆襄結石の経過観察例7例は癌を 発見された時点で進行癌であったことから, 胆囊 内腔の観察が困難な例, 壁構造から癌の合併が否 定できない例も手術を考慮する必要がある.

胆囊隆起性病変の診断には，癌の診断とともに 良性疾患の大部分を占めるコレステロールポリー プをいかに診断するかが重要である.コレステロ ールポリープは $10 \mathrm{~mm}$ 以下の例が多く, 15〜 $20 \mathrm{~mm}$ 以上のポリープは悪性の頻度が高率になる 13). $10 \mathrm{~mm}$ 以上でEUS等でコレステロールポリ 一プの典型像が得られず，癌を否定できない例は 手術を検討し, $10 \mathrm{~mm}$ 以下の例でコレステロール ポリープの診断のついた例は経過観察とするのが 一般的である3）13）14）.

コレステロールポリープはコレステロールを貪 
食した明るい泡沫状の胞体を有するマクロファー ジ（foamy cell）が主体の良性ポリープで15）, USで通常茎は細いため描出されず，点状高工 コーの桑実状パターンを示せば診断できる13). EUSでは点状高エコーの多粒子構造の形態が特 徵的であるが 17)，8～10mm前後になると腺増生 を伴い典型像が描出できず，実質性エコーパター ンを示すようになる13)。自験例でのEUSによる コレステロールポリープの正診率は $78.6 \%$ で, 腺 増生の著明な例, 内部に出血を伴った例は診断が 困難であった。

過形成ポリープには固有上皮の過形成および化

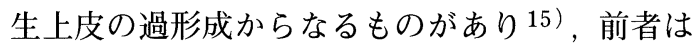
コレステロールポリープと類似した像を呈する 16). 自験例でも 3 例中 1 例は術前にコレステロー ルポリープと診断された。

腺腫は比較的高エコーを呈することが多く17）， Ip 型の腺腫内癌との鑑別は困難である ${ }^{16)}$ ，われ われの検討でも EUS で 5 例中 4 例は均一な高エコ 一を示し，Ip型の癌と鑑別は困難であった，2例 でコレステロールポリープにみられない太い茥を 描出でき, 茎の描出にも心がける必要がある.

腺筋腫症はRokitansky Aschoff sinus (RAS) が増殖し, 胆囊壁の筋層, 獎膜下層の肥厚を主体 とした病変である. 病変の局在・拡がりによって generalized type (fundal type ) - segmental type $\cdot$ localized type (fundal type ) に分類され るが，このうちlocalized typeは腫瘤として描出 されることが多く, 癌との鑑別を要する ${ }^{18)}$. RAS に一致する無エコースポット，壁内結石を反映す る comet like echoが描出できれば診断できるが 19), EUSで診断可能な病変はRAS1個の平均面 積が $0.4 \mathrm{~mm}^{2}$ 以上で，かつ $30 \%$ 以上の占拠率が必 要で 20$)$, 自験例でもEUSによる正診率は $57.9 \%$ にとどまり, 癌と鑑別の困難な例が多かった.

今回の検討で胆囊癌のうち, 癌の存在診断がで きた例では癌の肉眼型に一致した像がUSで明瞭 に描出され，有用であった。

\section{結語}

1.上腹部痛を有する胆囊結石例にはUSを行い， 急性胆震炎の所見があれば手術を検討する.

2. 炎症反応の高い例, 肝膿瘍を合併する例, 抗 生剤を投与して 2,3 日以内に症状が改善しな い例は緊急手術が必要である。基礎疾患を有 し，手術に危険を伴う例ではPTGBDを検討 する.

3. 充満結石例・急性胆串炎例では癌の併存に注 意し, USによる観察は注意を要する.

4. US・EUSでコレステロールポリープ・腺筋 腫症の典型像を示さない隆起性病変, $10 \mathrm{~mm}$ 以上の病変は癌を疑い手術を検討する必要が ある。

\section{文献}

1) 木村克己, 藤田直孝, 野田 裕, 他：胆道癌に対 する超音波集検の現状. 腹部画像診断, $1993 ; 13$ : $464 \sim 470$.

2 ) 濱島由紀, 石田秀明, 柿崎善明, 他 : 無症状疾患 とその対応 胆疾患. 臨床成人病, $1997 ; 27: 269$ $\sim 273$.

3 ) 三原修一, 黒田圭一郎, 吉岡律子, 他: 胆震ポリ ープの自然経過. 消化器内視鏡, $1997 ; 9: 729$ 733.

4) 平 明, 田中紜輝：胆輁コレステロールポリー プ：日本臨牃 (肝胆道系症候群 ), $1996 ; 6: 280$ $\sim 282$.

5 ) 谷村 弘, 石原扶美武, 小林展章, 他：1997年度 胆石全国調査報告. 胆道, $1998 ; 12: 276 \sim 293$.

6) 阿部朝美, 杉浦信之, 積田玲子, 他: 無症状胆石 の自然史に基づく治療法の選択. 胆と荤, 1998 ;

$19: 287 \sim 291$.

7 ) 伊勢秀雄, 内藤 剛, 龟田智統, 他: 無症状胆石 の臨床病理学的検討. 胆と膵, $1998 ; 19: 279$ 282 .

8 ) 林 雅造: 急性胆囊炎. 日本臨牀別冊 (肝-胆道 系症候群 ), $1996 ； 6 ： 206 \sim 209$. 
9) 酒井 滋, 山川達郎：腹腔鏡下胆囊摘出術. 医学

と薬学, $1998 ; 40: 835 \sim 838$.

10）三原修一, 黒田圭一郎, 吉岡律子, 他：超音波診 断による胆道癌のスクリーニング. 胆と膵, 1997 ; $18: 713 \sim 719$.

11）千々岩一男, 田中雅夫 : 無症候胆石症・胆震ポリ ープ. 臨床科学, $1995 ; 31: 1206 〜 1209$.

12 ) 佐藤 攻, 清水武昭, 内田克之: 急性胆囊炎を合 併した胆囊癌の臨床的検討. 日本腹部救急学会誌, $1993 ; \mathbf{1 3}: 861 \sim 866$.

13 ) 峰 徹哉：胆囊ポリープヘのアプローチ—診 断の観点から. 消化器内視鏡, $1997 ; 9: 735 \sim 739$. 14 ) 飯田俊雄, 川原田嘉文, 田端正己, 他: 胆囊ポリ ープヘのアプローチ—治療の選択. 消化器内視 鏡, $1997 ; 9: 741 \sim 747$.

15 ) 山口幸二, 横端和紀, 清水周次, 他: 胆囊ポリー
プヘの病理一一形態組織像. 消化器内視鏡, 1997 ; 9: $749 \sim 755$.

16）木村克己, 藤田直孝, 野田 裕, 他：「胆震ポリ 一プ」のEUS像と病理. 消化器外科, $1996 ; 19$ : $199 \sim 211$.

17）杉山政則, 和田信昭, 黒田 慧：超音波内視鏡に よる胆囊隆起性病変の分析. 胆と膵, $1993 ; 14$ : $1349 \sim 1352$.

18) Jutras JA, Longtin JM, Levesque HP, et al. : hyperplastic cholecystoses. AM J Roentogenol, $1960 ; 83: 795 \sim 827$.

19 ）鶴長泰隆, 福井 洋, 塩籠利昭, 他: 胆震腺筋腫 症をめぐって 超音波診断. 腹部画像診断, 1992 ; $12: 248 \sim 255$.

20）若林 香, 有山 襄, 須山正文, 他：胆囊癌の画 像診断. 消化器外科, $1995 ; 18: 1326 \sim 1332$.

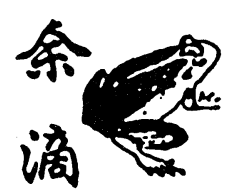

最近, 街行く若い人々の様相が一変した. ヤマンバ ギャルやビジュアルバンド系の男子, これに属する人 達である. 道路上, 交叉点, 階段の昇降, 電車の中で その足もとが気になる。怪我をしないかと余分の心配 もする. 健康増進ブームにのって多目的な靴が店頭を 賑わしているが, 流行靴は勿論のこと常用の靴につい ての医学的研究は意外と少ない.

人間の体重を支え歩行の基点となる部位は，下腿と 足との直結する足関節である. 足の構造は可動性のあ る前足部，足の横アーチを形成し，掛ける体重を増减 する柔軟性に富む中足部，また足根骨で直立したとき に安定度を制御する後足部から成り立っている。 それ に対して靴は底の厚さやヒールの高さ, 甲の締め方, 前足部のゆとり，踣返し部位の柔軟性や踵骨内側部の 保護など，足の構造や機能を十分配虑されていなけれ ばならない.さらに元城南病院の石塚忠雄院長は「靴 と足の医学」(東京都医師会雑誌, $1994 ; 47 ： 11$
22 ) のなかで, 足を十分に機能させるために載距突起 部位を足の長軸 (怪骨の縦中心線と, 横外側に移行し 踵骨中央に妨けて地面に達する線）に対して足関節全 体の回内位傾向を防ぐよう常に $90^{\circ}$ にするよう補正し なければならないとのべている，厚底が高くなるほど 足関節の形成が最も重要視されている距骨下関節の載 距突起がより一層不安定となり, 怪骨・大腿骨をえて 大腿骨々頭部の中心線が動摇し, 起立時・歩行時のバ ランスを崩し骨折や勒帯損傷をひきおこしやすくなる. 前足部の運動機能も低下し感覚も衰える. 某大手企業 の通勤時の禁止や車運転時の装用の罰則導入は当然の ことである.

一時的ファッションとはいえ, MG5 (マチ切れ5秒 前), ガスター10（ムカつく）の流行語の生れる世情 で, 心の健康は足を地につけ足もとをみつめることか らはじまる。

（打茶の水相互クリニック 森近 浩） 